\title{
Benin: Ex Post Assessment of Performance Under Fund-Supported Programs
}

This Ex Post Assessment of Performance Under Fund-Supported Programs for Benin was prepared by a staff team of the International Monetary Fund as background documentation for the periodic consultation with the member country. It is based on the information available at the time it was completed on September 3, 2004. The views expressed in this document are those of the staff team and do not necessarily reflect the views of the government of Benin or the Executive Board of the IMF.

The policy of publication of staff reports and other documents by the IMF allows for the deletion of market-sensitive information.

To assist the IMF in evaluating the publication policy, reader comments are invited and may be sent by e-mail to publicationpolicy@imf.org.

Copies of this report are available to the public from

International Monetary Fund $\bullet$ Publication Services

700 19th Street, N.W. • Washington, D.C. 20431

Telephone: (202) $6237430 \bullet$ Telefax: (202) 6237201

E-mail: publications@imf.org • Internet: http://www.imf.org

Price: $\$ 15.00$ a copy

\section{International Monetary Fund}

Washington, D.C. 



\section{INTERNATIONAL MONETARY FUND}

\section{BENIN}

\section{Ex Post Assessment of Performance Under Fund-Supported Programs}

Prepared by a staff team from the African, Fiscal Affairs, and Policy Development and Review Departments ${ }^{1}$

Authorized for distribution by the African and Policy Development and Review Departments

September 3, 2004

Contents

I. Introduction

II. The Economic Situation Before the Period Under Review ..........................................

III. Performance Under the ESAF and PRGF Arrangements ..........................................

A. Objectives of Fund Involvement Since 1993 ....................................................

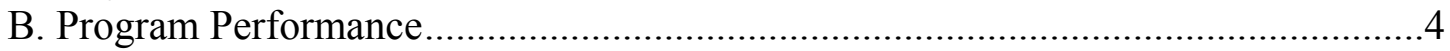

IV. Lessons Learned and Policy Challenges for the Medium Term ..................................11

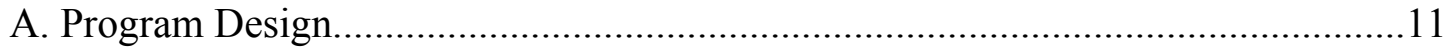

B. Compliance with Program Conditionality........................................................... 12

C. Collaboration with the World Bank and Other Development Partners....................14

D. Policy Challenges for the Medium Term ........................................................ 14

V. Future Fund Relations with Benin ....................................................................... 19

Boxes

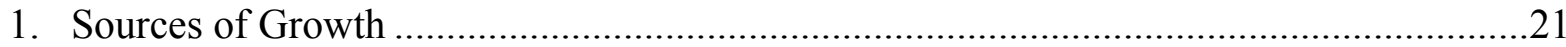

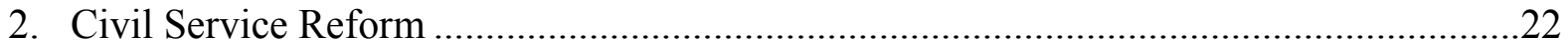

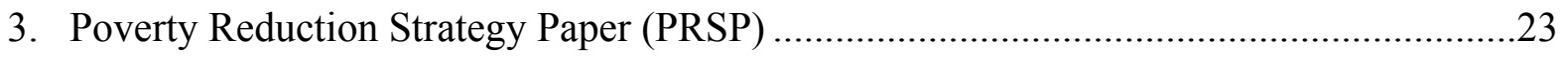

${ }^{1}$ The team comprised P. Ewenczyk (head), F. Nsengiyumva, M. Yulek (all AFR), N. Calcoen (FAD), and Z. Ebrahim-zadeh (PDR). 
Figures

1. Output, Prices, and Real Exchange Rates, 1989-2003 .............................................24

2. Government Finance and Monetary Indicators, 1989-2003

Tables

1. Macroeconomic Performance Under the Program, 1993-2003 .26

2. Program Performance Criteria, Structural Benchmarks, and Prior Actions, 1993-2004

3. Breakdown of Structural Conditionality and Comparison with all ESAF and PRGF Programs

Appendix

Performance on Structural Conditionality Under ESAF/PRGF

Programs, 1992-2004. 


\section{INTRODUCTION}

1. This paper assesses Benin's progress in implementing economic policies and reforms supported by the Enhanced Structural Adjustment Facility (ESAF) and Poverty Reduction and Growth Facility (PRGF) arrangements since 1993 and draws lessons for a possible successor arrangement. Section II briefly presents developments prior to these arrangements, including the comprehensive stabilization and liberalization of the economy starting in 1989. Section III reviews the performance under the three arrangements during the period 19932003. Section IV draws some lessons from these program experiences and considers the main challenges facing Benin. Section V discusses the role the Fund could play in helping the authorities meet those challenges.

\section{The Economic Situation Before the Period Under Review}

2. Following years of central economic planning and a monoparty system, Benin embarked in 1989 on sweeping economic and political changes. A new economic development strategy was devised, which emphasized the reduction of the role and size of the public sector, the return to fiscal discipline, and the central role of private initiative. This process of economic liberalization was supported by two Structural Adjustment Facility (SAF) arrangements covering the period 1989-92. In parallel, multiparty democracy was introduced successfully, with the peaceful transfer of power to an elected president and the establishment of an independent National Assembly.

3. The adjustment and reform policies implemented during 1989-92 resulted in significant improvements in Benin's macroeconomic and financial performance. Following four years of stagnation, real GDP increased by 4 percent per year on average during 1990-92; the fiscal deficit was reduced from 11 percent of GDP in 1989 to 5 percent of GDP in 1993; and gross official reserves rose from the equivalent of two weeks of imports at end1989 to five months at end-1992. The rehabilitation of the banking system-which involved the liquidation of state-owned banks and their replacement by private banks operating on commercial terms - led to a steady return of confidence in the financial sector. Major actions were taken to liberalize the economy, including the elimination of import licensing and of most quantitative restrictions on imports, the streamlining of the labor code and of the regulations governing the formation and registration of private enterprises, the elimination of the monopoly of state enterprises in domestic trade, and the privatization and liquidation of a number of public enterprises.

\section{Performance Under the ESAF ANd PRGF ARRAngements}

\section{A. Objectives of Fund Involvement Since 1993}

4. Following this initial period of transition to democracy and a market-based economy, Benin has had three successive arrangements with the Fund. First was an ESAF arrangement 
covering the period January 1993-January 1996 (extended through May 1996) for an amount of SDR 46.95 million (103.6 percent of quota). The approved amount was subsequently increased to SDR 51.89 million, out of which SDR 48.39 million was drawn. Second, an ESAF arrangement covered the period August 1996 - August 1999 for an amount of SDR 27.18 million (60 percent of quota). The implementation of key structural reforms under this arrangement incurred delays, ${ }^{2}$ and, although the arrangement was extended through July 2000, it expired before the second annual program could be completed, with only SDR 16.31 million drawn. Third, a PRGF arrangement covered July 2000-July 2003 (subsequently extended through March 2004) for an amount of SDR 27 million (43.6 percent of quota), which was fully drawn.

5. All three programs supported under the ESAF and PRGF arrangements aimed at reinforcing the foundations for sustained private-sector-led growth and reducing poverty through fiscal consolidation, an increase in poverty-reducing outlays, and a deepening of structural reforms. Key structural issues included improving civil service efficiency, divesting the key remaining public enterprises, liberalizing the cotton sector, and strengthening the financial sector.

\section{B. Program Performance}

\section{Macroeconomic developments}

6. Since 1993, Benin has made major progress in macroeconomic stabilization (see Table 1; and Figures 1 and 2). Sound macroeconomic policies, together with the devaluation of the CFA franc in January 1994 and the implementation of structural reforms, helped sustain a steady economic growth of 5 percent a year on average during the period 19932003, in line with the objective of the programs. The growth rates achieved were comparable to those of other well-performing West African Economic and Monetary Union (WAEMU) countries - including Burkina Faso, Mali, and Senegal. The analysis of the sources of growth, based on a standard production function, shows that the increase in growth performance was mainly driven by a larger contribution from capital accumulation and a positive contribution from total factor productivity (TFP), reflecting an increase in public investment sustained by inflows of external assistance, and some progress achieved in implementing structural reforms (Box 1). However, the diversification of the economyfrom cotton production - has remained elusive, pointing to possible problems regarding competitiveness and the environment for private sector investment. Moreover, the continued sizable flow of Benin's exports to Nigeria is a cause of concern, because it is largely in the form of smuggling - reexports to Nigeria of goods imported through the Port of Cotonou for which there are import restrictions in Nigeria - and is therefore vulnerable to changes in trade policy in Nigeria. Furthermore, even products that are not prohibited for import into

\footnotetext{
${ }^{2}$ The reforms included the civil service reform, the reform of the cotton sector, and the implementation of a price mechanism for petroleum products.
} 
Nigeria have been subject to sudden, unexpected changes (because of changes in the list of prohibited imports or temporary closure of the border)

7. The prudent regional monetary policy conducted by the Central Bank of West African States (BCEAO) helped keep inflation low during 1993-2003 - except in 1994-95, when the effects of the devaluation worked their way through the economy. Excluding these two years, inflation averaged 3 percent, which is in line with that of the euro zone, the currency to which the CFA franc is pegged. Benin contributed positively to the net foreign assets of the regional central bank (Figure 2), and its external current account deficit, excluding official grants, hovered around 8 percent of GDP, broadly in line with program targets.

8. Based on the real effective exchange rate indicator, Benin has preserved about 25 percent of the external competitive gains from the devaluation of the CFA franc in 1994, while the terms of trade remained broadly stable on average. Half of the competitive gains were lost by end-1995, owing to the initial surge in price in 1994-95 that followed the parity change. ${ }^{3}$ The real effective exchange rate remained stable from end-1995 to end-2000, as inflation was brought under control. During 2001-03, competitive gains eroded again by 25 percent, reflecting an appreciation of the euro, to which the CFA franc is pegged.

9. The financial sector was strengthened considerably, following its collapse in 1989-90 and its subsequent rehabilitation in the early 1990s. Bank deposits, which had dropped to their lowest level in 1990, expanded rapidly with the return of confidence in the financial system, and bank credit to the nongovernmental sector increased steadily from 4 percent of GDP in 1993 to 13 percent of GDP in 2003 (Figure 2). ${ }^{4}$ This financial deepening was buttressed by the supervision of the regional banking commission created in 1990, and by the government's efforts to ensure that commercial banks comply with the regional prudential ratio requirements. Nonperforming loans fell from 9 percent of total credit in 1995 to 5 percent in the early 2000s. In parallel, microfinance institutions developed, with deposits increasing from 0.7 percent of GDP in 1993 to 1.7 percent of GDP in 2002.

\footnotetext{
${ }^{3}$ Cumulative inflation in 1994-95, of 60 percent, was larger than in the other countries of the WAEMU (45 percent on average), reflecting sizable wage and salary increases in the public sector, as well as adjustments on account of past wage arrears, totaling over 50 percent.

${ }^{4}$ The increase in bank credit was accompanied by a diversification in terms of sectoral allocation, driven by construction and trade sectors. The assessment of financial deepening is not based on broad money indicators because the measurement of currency in circulation has been subject to large uncertainties, arising from long delays in the sorting of the banknotes by the BCEAO. This has led to frequent, sometimes very large, changes in the measurement of currency in circulation and gross foreign assets of the BCEAO.
} 
10. Together with other WAEMU countries, Benin has maintained a liberal trade and payments system, since the elimination of import-licensing requirements and nontariff barriers in the early 1990s. In 2000, the regional common external tariff (CET) was implemented, including simplified tariff rates and steps toward a progressive elimination of tariffs within the WAEMU area. Nevertheless, the regional CET and categorization of products introduced in 2000 resulted in an increase in average tariffs.

11. Benin's sound macroeconomic policies helped it reach the completion point under the enhanced Heavily Indebted Poor Countries (HIPC) Initiative in March 2003. Debt relief obtained under the initiative, which amounts to US\$265 million in net present value (NPV) terms, was critical in reducing the ratio of the NPV of debt to exports of goods and nonfactor services to 161 percent at the completion point; the debt ratio is expected to decline further to below the threshold of 150 percent from 2005 onward, according to the debt sustainability analysis underlying the completion point. Benin's debt management has been strengthened recently with the establishment of a National Debt Committee.

\section{Fiscal policy and budget reform}

12. Fiscal consolidation improved substantially during the successive programs (Table 1 and Figure 2), as the key initial challenges arising from the low level of revenue collection and the high level of the wage bill were addressed. As a result, Benin has been one of the most compliant members of the WAEMU regarding the convergence criteria adopted in 1999, and the government's position with the banking system improved dramatically from a net debtor's position equivalent to 15 percent of GDP in 1990 to a net creditor's position, starting in 1999.

13. Improving revenue performance was a key issue and a major achievement under the programs. Starting from one of the lowest levels in Africa (7.2 percent in 1989), the tax revenue-to-GDP ratio increased rapidly to 12.3 percent in 1995 , then continued to rise, although at a slower pace, reaching 15 percent in 2002-03. Both domestic and customs revenues more than doubled as shares of GDP over the period, despite persistent weaknesses at customs.

14. On the domestic taxation side, major tax policy reforms were implemented from 1990 to 1996, including the introduction of a single-rate value-added tax (VAT) (with a broad base and few exemptions), the reduction of the corporate profit tax, and the simplification of small business taxation and of the personal income tax. These reforms were supported by major improvements in tax administration, including changes in collection procedures (the collection function was transferred from the treasury to the tax administration) and the establishment of a large taxpayer unit. The successful domestic tax reform strategy implemented in Benin during the first half of the 1990s was later used as a 
model in many other French-speaking countries in Africa. Tax administration deteriorated somewhat in the mid-1990s, ${ }^{5}$ but steps were taken, starting in 1998, to redress the situation.

15. Regarding customs reforms, along with the increase in average tariff, the computerization of customs was extended to all customs offices. Collection of taxes at customs also benefited from the introduction of the VAT and the devaluation of the CFA franc. Implementation of the CET, however, was associated with continued fraud and corruption, as inappropriate customs practices, entailing an undervaluation of imports, were developed in order to compensate for the increase in tariff rates and facilitate the smuggling of goods to neighboring countries. These practices provided more opportunities for negotiation of customs liabilities and, hence, for fraud and corruption. To address these weaknesses, actions have been taken recently to strengthen customs administration, apply transaction values to all imports, and fight smuggling. The lack of control over exemptions (régimes suspensifs) and corruption among customs officials, however, remains a major concern.

16. On the expenditure side, the civil service reform has been one of the major elements of the government program since 1989, with the objective of containing the wage bill and strengthening the efficiency of the public administration. Considerable success was initially achieved in reducing the wage bill through the implementation of a voluntary retirement program that led to more than 6,000 departures and an attrition policy that allowed only two replacements for every three departures. As a result, the wage bill declined by $2 \frac{1}{2}$ percentage points of GDP from 1989 to 1996. Furthermore, the authorities had frozen wages during 1987-92, which, despite the continuation of the automatic advancement, resulted in actual salaries being significantly lower than grade-based salaries; the gap was gradually eliminated during 1992-2003 (Box 2). However, the second stage of the civil service reform, aiming at replacing the costly and inefficient automatic advancement mechanism by a performance-based promotion and remuneration system, has stalled since 1998, due to a disagreement within the government coalition, as well as to a strong opposition from trade unions and parliament. The authorities temporarily bypassed this obstacle by starting to recruit new staff on a contractual basis, but they recently recognized that a new advancement and compensation system based on performance needed to be designed, and they have accordingly started discussing the matter with the unions since mid-2003.

17. Despite progress in fiscal consolidation, public expenditure management remained weak during most of the period. ${ }^{6}$ In particular, notwithstanding successive plans to settle

\footnotetext{
${ }^{5}$ Tax administration was weakened following the lowering of the VAT threshold, as the effectiveness of taxpayer controls and audits deteriorated.

${ }^{6}$ Weaknesses in public expenditure management and fiscal transparency were identified in the Report on the Observance of Standards and Codes and the Assessment of the Capacity to
} 
them since 1991, domestic arrears persisted through $2001^{7}$ — with the exception of cross arrears with public utility companies, which are being audited. ${ }^{8}$ Also, the rate of execution of priority social spending remained low; the actual increase in health and education expenditures in recent years (from 3.4 percent of GDP in 1996 to 5.6 percent of GDP in 2003) mostly reflected the use of HIPC Initiative relief funds since 2000 . To remedy the situation, Benin has embarked since 2000 on a major public expenditure management reform program, with the assistance of the World Bank, including the implementation of an integrated computerized expenditure management system (SIGFIP), a move toward performance-based budgeting through program budgets formulated within a medium-term expenditure framework, and the delegation of spending authority from the Ministry of Finance to line ministries. In addition, a mechanism to track all poverty-reducing public spending was put in place in 2003. These reforms are just starting to produce results. However, some important weaknesses remain in the public expenditure management system, including internal controls and accounting, as reported in the Assessment and Action Plan (AAP) of the Capacity to Track Poverty-Reducing Expenditure undertaken in 2003.

\section{Structural reforms}

18. Overall progress in structural reforms was mixed. Following successful initial efforts to liberalize the economy and reduce government intervention, reforms have incurred significant delays, especially regarding the divestiture program. As with civil service reform, these delays were due to disagreements within the coalition government in 1997-98, the absence of government majority in the National Assembly through 2003, and the growing opposition of the unions to the divestiture of the Port of Cotonou.

19. Key reforms during the first half of the 1990s included abolishing government monopolies and liberalizing prices and trade. ${ }^{9}$ In parallel, a significant number of state enterprises was privatized. ${ }^{10}$

Track Poverty-Reducing Expenditure undertaken in 2001, including internal control, budget reporting, and accounting.

${ }^{7}$ Inventories conducted in 1992, 1995, and 1999 identified domestic arrears amounting to about 7 percent of GDP. Quantitative benchmarks or performance criteria on reduction of domestic arrears were included in programs until these arrears were fully cleared in 2001 .

${ }^{8}$ The 2003 Assessment and Action Plan (AAP) of the Capacity to Track Poverty-Reducing Expenditure also identified deficiencies in the recording of commitments generated by public procurement contracts, which have subsequently been corrected.

${ }^{9}$ By 1995, products subject to price controls were limited to petroleum products, cement and utility tariffs. Subsequently, an automatic price adjustment mechanism for petroleum products was introduced in 1999, and cement prices were liberalized in 2002. Government monopolies were abolished (in transport, port handling and insurance, and the cotton sector). 


\section{Benin also made significant progress in introducing far-reaching reforms to} liberalize the cotton sector - a key sector that accounts for about 70 percent of exports of goods and provides the major cash crop. Private operators currently control about 50 percent of the installed ginning capacity, and the privatization of the government-owned ginning plants is under way. The sector's stakeholders (ginners, input suppliers, and cotton farmers' associations) have the responsibility, through an independent, privately-managed umbrella institutions, to set the producer price, allocate seed cotton among ginning companies, oversee input distribution and ensure the payment to producers and the recovery of input credit. However, this institution has experienced recurrent cash-flow problems, because some ginners did not pay for the cotton received and some inputs were sold outside the new institutional setup.

\section{The divestiture program for public utilities, however, has incurred protracted}

delays. The government adopted strategies for the privatization of the electricity distribution sector and telecommunications, and for the involvement of the private sector in the management of the Port of Cotonou; initial steps for the implementation of these strategies were taken. ${ }^{11}$ Nevertheless, the authorities still need to establish new, realistic timetables and a transparent process for these privatizations.

22. Regarding governance, a series of initiatives has been taken to strengthen the legal and judicial system and combat corruption. At the WAEMU level, business laws have been harmonized, and a regional Court of Appeals has been established. The authorities also adopted, in 2001, a ten-year development program for the legal and judicial systems, and, in 2002, an anticorruption strategy, which calls for improved anticorruption laws and the strengthening of the government audit departments. In addition, divestiture procedures were strengthened lately, with the assistance of the World Bank, for SONAPRA privatization. However, implementation of these initiatives has been slow and has not yet resulted in a significant improvement in the judicial system and in the institutions responsible for implementing the divestiture program.

${ }^{10}$ As a result, the number of enterprises in the government's portfolio declined from $65-$ when the privatization program started in 1988 - to 11 in 2003. Major privatization initiatives since 1993 included the petroleum products distribution company (SONACOP), the cement factory (SCO), the palm oil company (SONICOG), the sugar factory (SSS), and the insurance company (SONAR). In addition, state-owned palm oil plantations were transferred to farmers' organizations.

${ }^{11}$ These included the separation of the different entities within each utility company and the adoption of a decree for the establishment of a regulatory body for the telecommunications sector. 


\section{Poverty reduction}

23. Sustained growth allowed per capita incomes to rise (by 2 percent a year on average during 1993-2003), ${ }^{12}$ and most social indicators to improve steadily, including those for education and health. But Benin's Poverty Reduction and Strategy Paper (PRSP), presented to the Executive Board in March 2003, indicated that these achievements did not translate into significant progress in poverty reduction. According to the results of the poverty assessments conducted in 1995/96 and 1999/2000, the incidence of income poverty increased significantly during the second half of the 1990s, from 25 percent to 33 percent in rural areas, where 60 percent of the population lives, while decreasing from 29 percent to 23 percent in urban areas.

24. Against this background, the PRSP presented a comprehensive poverty reduction strategy framework (Box 3). The PRSP, however, suffered from important shortcomings, according to the joint staff assessment; ${ }^{13}$ including the lack of a clear analysis of the key determinants of poverty, as it did not benefit from a full analysis of the impact of past policies on the poor, and major methodological weaknesses remained. Also, Benin experienced difficulties in organizing the PRSP process, as well as delays in finalizing a full PRSP ${ }^{14}$ which reflected in part weaknesses in the institutional framework of the PRSP.

25. Because of the long delay in producing a full PRSP, the budget for 2004 is the first one to reflect the priorities of the comprehensive poverty reduction strategy. It was prepared with the support of all major donors, in an effort to align their financial assistance with the budgetary process. In accordance with the more ambitious scenario of the PRSP, the budget commits higher expenditure to priority sectors. In parallel, the authorities have enhanced the tracking of poverty-reducing expenditures in order to improve their execution rate.

\section{Statistical database}

\section{Benin's statistical database is fairly comprehensive but remains weak in a} number of areas, particularly in national accounts, balance of payments, public finance, monetary statistics, and social indicators. The deficiencies in the database did not hamper, however, the ability of Fund staff to conduct policy evaluation. Benin has participated in the Fund's General Data Dissemination System (GDDS) since 2001 and, in consultation with Fund staff, has set out plans for the improvement of its statistical database. Also the

\footnotetext{
${ }^{12}$ Per capita GDP increased from the equivalent of US\$411 in 1993 to US\$521 in 2003.

${ }^{13}$ Benin - Poverty Reduction Strategy Paper_-Joint Staff Assessment (Country Report 03/111).

14 The delay was mainly due to the postponement of the PRSP consultation process until after the presidential elections in March 2001, and difficulties in establishing the institutions in charge of the preparation of the PRSP.
} 
authorities have recently started implementing the set of rules harmonizing the methodology for compiling the national accounts of all the WAEMU countries. Furthermore, an action plan is being implemented to address methodological weaknesses in compiling poverty data and other social indicators.

\section{Lessons Learned and Policy Challenges for the Medium Term}

\section{A. Program Design}

27. The programs supported by the Fund appropriately focused on economic and financial stabilization, and on structural reforms essential to liberalize the economy and raise growth. Program assumptions proved to be realistic; in particular, economic growth was in line with objectives, as the authorities implemented the key policy measures envisaged in the programs. Given that Benin is a member of the WAEMU, fiscal adjustment was the centerpiece of the stabilization strategy; it was underpinned by measures to broaden the tax base, improve tax administration, rationalize expenditure, and redirect resources toward priority social programs.

28. The programs benefited from substantial technical assistance from the Fund, mostly in the fiscal area. On the revenue side, assistance focused on modernizing the tax system and improving tax and customs administration through the assignment of resident advisors during 1989-94 and several follow-up missions. Combined with a strong commitment from the authorities, the IMF technical assistance program was effective in improving revenue collection and in building technical capacity in the tax administration. Regarding customs administration, where the implementation of the CET was associated with continued fraud and corruption, the 2002 technical assistance mission recommended a set of measures to address governance issues. A comprehensive action plan incorporating the recommendations of the mission was adopted in March 2003 by the authorities, who have started implementing it. On the expenditure side, provision of technical assistance by the Fund was more limited, except in 1990-92 when a long-term expert was assigned to Cotonou. Since 2000, the World Bank has taken the lead in assisting the authorities in a vast reform program of public expenditure management, in close collaboration with the Fund, including in the context of joint assessments of the capacity to track poverty-reducing expenditure. This has helped the authorities strengthen budget execution, in particular, through the implementation of the new computerized budget management system. Benin has also benefited from regional technical assistance to the WAEMU countries in the area of balance of payments and monetary statistics; the databases in these areas, however, have remained weak.

29. While programs included contingencies for the shortfall in aid flows, exogenous shocks were not addressed ex ante. However, when Benin was faced with an unexpected drop in the world price for cotton, as was the case in the second half of 2001, adequate flexibility was shown by adjusting fiscal targets ex post; budgetary expenditure and deficit targets were revised upward to accommodate a onetime government subsidy to the producer 
price. Also, programs allowed for a significant increase in expenditures in priority sectors to accommodate higher than initially expected external budgetary assistance, as well as debt relief obtained under the HIPC Initiative. ${ }^{15}$

30. Structural conditionality became increasingly focused on areas of Fund core expertise, including fiscal measures with respect to tax and customs administration, and fiscal management and transparency (Table 3). Conditions outside Fund core areas, which were restricted to a limited number and focused on key reforms during the 1990s, further decreased by half to only 25 percent of total conditions under the last PRGF arrangement for Benin — while they remained at 42 percent in PRGF-supported programs for all countries during the same period. While this drop reflected in part the completion of the first generation of reforms, it also resulted from efforts in the context of the last PRGF arrangement to limit conditionality in noncore areas to measures that were key to the success of the macroeconomic program, including the reform of public enterprises that ran large quasi-fiscal losses, the implementation of a new compensation system for civil service to moderate salary increases, and the implementation of the strategy for the privatization of SONAPRA - which was a trigger for reaching the completion point under the enhanced HIPC Initiative completion point.

31. The programs could have moved more quickly to emphasize the need to strengthen external debt-management capacity. The debt sustainability analysis supporting the enhanced HIPC Initiative completion point, which was conducted in 2002 , highlighted the fact that the debt-to-exports ratio was higher than expected at the decision point because new government borrowings had been larger than anticipated; this increase in new borrowing was mostly due to a change in the financing strategy of government projects in favor of loans. The PRGF arrangement did not set appropriate limits on external borrowing at the time of the decision point. ${ }^{16}$ On the basis of these results, the authorities agreed to set a cap on the borrowing requirement of the government in the form of a performance criterion for the last two reviews under the PRGF arrangement and established a debt committee, which became operational at end-2003, to monitor debt policy.

\section{B. Compliance with Program Conditionality}

32. Program implementation under the ESAF and PRGF arrangements was broadly successful. Most quantitative performance criteria included in the annual programs were met

${ }^{15}$ Over 2000-03, the average annual disbursements of external budgetary assistance and debt relief amounted to 1.6 percent of GDP, compared with the 0.7 percent expected in the original PRGF arrangement.

${ }^{16}$ External debt with a maturity of one year or more contracted by the government was to be concessional, but there was no quantitative limit to such borrowing. 
(56 out of 62; see Table 2), reflecting Benin's strong macroeconomic performance and fiscal consolidation. ${ }^{17}$

33. However, implementation of key structural measures was uneven, resulting in protracted delays in meeting some structural conditions (Appendix I). Indeed, the third review under the second annual arrangement of the ESAF approved in 1996 could not be concluded before the arrangement expired, owing to delays in implementing key structural reforms in the cotton sector and the civil service, and, ultimately, the nonobservance of a key prior action regarding the setting of prices for petroleum products. Furthermore, the quarterly quantitative structural benchmarks on government social spending for health and educationestablished since 1998-were generally not fully met.

\section{The mixed record of structural policy implementation calls into question the} extent of program ownership. The pace of structural reforms suffered from the government's difficulties in reaching the necessary political consensus on key reforms, notably in the cotton sector, the civil service reform, and the privatization of the Port of Cotonou. Also, there was insufficient coordination in decision making within the government; in particular, the government's five-year action plan for 2001-06, which was prepared separately from the work on the PRSP and the Medium-Term Expenditure Framework (MTEF), scheduled large infrastructure projects that were not assessed for their contribution to growth and poverty reduction.

35. Weak institutional and administrative capacity was also a major constraint on the implementation of structural policy. Delays in the implementation of the divestiture program, in particular, were in part due to the persistent weak capacity of the unit in charge of the preparation and coordination of privatization, despite technical assistance provided by the World Bank. Weak implementation capacity also hampered the execution of government social expenditures, although increased delegation of spending authority to line agencies, together with the development of a MTEF for the key sectoral ministries, has recently helped to improve their execution rate. A plethora of donor-funded projects further burdened administrative capacity; this reflected a lack of coordination among donors prior to the completion of the PRSP, as well as their reluctance to engage in program financing because of the weak public expenditure management in the 1990s.

36. There was also a long delay in completing a full PRSP, ${ }^{18}$ which was finalized at end-2002 rather than October 2001, as had been envisaged at the time Benin reached its

\footnotetext{
${ }^{17}$ The targets set in the original three-year PRGF arrangement were adjusted subsequently in the annual programs to accommodate higher than originally anticipated external budgetary assistance and debt relief under the HIPC Initiative.

${ }^{18}$ As mentioned above, the delay was mainly due to the postponement of the consultation process until after the presidential elections in March 2001.
} 
decision point under the enhanced HIPC Initiative in July 2000. This delay hampered efforts to closely align the PRGF program with the PRSP and to track poverty-reducing expenditure.

37. In summary, past program design has been broadly appropriate, but has underestimated the weakness in the authorities' administrative and implementation capacity, as well as the weak internal consensus in favor of structural reforms. However, Fund structural conditionality has been eased over time, while fiscal targets have been adjusted on several occasions to accommodate the impact of shocks. More broadly, Fund-supported programs have not explicitly recognized the Benin's vulnerabilities to exogenous shocks. However, in practice, this issue was addressed by frequent reassessments of the macro framework, and continued emphasis on accelerating structural reforms and promoting production and export diversification.

\section{Collaboration with the World Bank and Other Development Partners}

38. The Fund's collaboration with the World Bank has been close and productive. Bank and Fund teams have closely coordinated their policy advice to the authorities, as well as the determination of their respective structural conditionality. The World Bank has played a leading role in supporting structural reforms -including the cotton sector reform, the divestiture program, the civil service reform, and social sector reforms. In the fiscal area, it has assumed a key role in supporting public expenditure management reform, budgetary allocation to priority sectors, and the strengthening of the public sector procurement system. In the financial sector, the World Bank has provided support to microfinance institutions.

39. In an effort to align its support program with the PRSP, the World Bank is increasingly refocusing its assistance from project to budgetary support through annual Poverty Reduction Support Credits (PRSCs), which aim at helping Benin implement its poverty reduction strategy and strengthening the government's capacity to carry it out. Annual PRSCs, aligned with the government's budget cycle, would become a key vehicle for Bank support to the country over 2004-06, with commitments reflecting the level of government performance. The first PRSC was approved in March 2004. In parallel, projects would continue in the areas of community development, decentralization, and electricity services.

40. Other development partners, including the European Union, the African Development Bank, and bilateral donors, have also provided substantial support to the implementation of the government's economic reform program during the period in the form of project and budgetary assistance. The PRSP preparation process has fostered collaboration among donors. In particular, along with the World Bank, key donors (the European Union, the African Development Bank, Denmark, the Netherlands, and Switzerland) have been aligning their assistance with Benin's poverty reduction strategy for 2004-06.

\section{Policy Challenges for the Medium Term}

41. In accordance with the objectives of the PRSP, the main challenge for the future is to reach a higher and sustained growth rate and reduce poverty, while preserving 
and reinforcing macroeconomic stability and making the economy less vulnerable to external shocks. To this end, Benin should (i) restructure budgetary allocations in favor of poverty-reducing expenditures; (ii) accelerate the implementation of structural reforms, as they are key to raising productivity and improving service delivery in public utilities and the Port of Cotonou, and to increasing producers' share of export proceeds in the cotton sector; and (iii) encourage private investment in order to foster economic growth and diversification from dependence on cotton production and trade with Nigeria, in particular through improved governance and transparency - including by strengthening the judiciary system and divestiture procedures, and fighting corruption at customs.

42. To achieve the objectives of the PRSP and make progress toward reaching the Millennium Development Goals (MDGs), the PRSP aims at reaching a sustainable economic growth of at least 7 percent, starting in 2005. The results of the growth-accounting exercise (Box 1) suggest that such a target could be achieved by increasing investment (by at least 1.5 percentage points of GDP) and raising the average growth rate of total factor productivity (from 1 percent to 2 percent). In that respect, foreign direct investment is expected to play a key role, as it would increase the stock of capital and generate technological spillover effects that could help improve TFP.

\section{Fiscal reforms}

43. The overall objectives for the future in the fiscal area would be to increase the level and quality of poverty-reducing spending and improve governance and transparency at customs, while keeping the government deficit in line with the objective of debt sustainability. ${ }^{19}$

44. Further efforts will be required to increase the tax-to-GDP ratio in order to achieve the WAEMU convergence criterion (17 percent of GDP). This target should be reached mainly by further strengthening the tax and customs administration. In accordance with the recommendations made recently by an FAD technical assistance mission, key measures should include combating tax evasion, tightening controls, and continuing the simplification of procedures. Special attention will have to be paid to control exemptions at customs to ensure a full implementation of the World Trade Organization (WTO) valuation rules for imports.

${ }^{19}$ The PRSP aims at keeping the fiscal deficit, including grants, unchanged at about 2 percent of GDP over 2004-06, while substantially increasing priority expenditures in order to make progress toward reaching the MDGs. Additional priority expenditures are to be financed mostly by external grants in the short and medium term, as well as by additional revenue effort in the long run. Nonpriority expenditures are to be contained at their current ratio to GDP. 
45. Efforts to reflect PRSP priorities in budgetary allocation, which were initiated with the preparation of the budget for 2004, should be pursued. In parallel, to improve the efficiency and transparency of public spending, the reforms under way in public expenditure management will have to be completed and all their potentialities fully utilized (e.g., SIGFIP to improve budget reporting, and program budgeting to improve allocation and efficiency). In that respect, the 2003 AAP, prepared jointly by Fund and World Bank staffs, provides a useful road map of measures. Also, much work remains to be done to improve performance indicators, as well as the monitoring and evaluation of priority expenditure.

46. A new compensation and promotion system still has to be agreed upon that incorporates the objectives of the stalled civil service reform geared toward improving the quality and efficiency of public services, and moderating salary increases. Further wage increases should be linked with the implementation of such a new compensation and promotion system, and reflect productivity gains.

47. In the meantime, Benin will be faced with the consequences of its aging civil service workforce, which will entail a rapidly rising number of civil servants reaching retirement age. $^{20}$ This will be an opportunity to improve the efficiency of the public administration through a better allocation of civil servants, which, in turn, will require progress in the reform of public administration, including a reorganization of ministries and the preparation of staffing plans. It will also pose challenges for the recruitment policy and require the rapid formulation of a strategy to ensure the financial viability of the civil service pension fund (FNRB).

48. The decentralization process, which is expected to gain momentum following the recent municipal elections, will also have to be carefully monitored. Local governments are expected to have increased spending responsibilities. This should be associated with adequate resource-sharing arrangements, the implementation of effective local budget reporting and control mechanisms, and a strengthening of the technical capacity at the local level.

49. The large infrastructure projects scheduled under the Government Action Program — including a new port and a new airport — have not yet been assessed for their contribution to growth and poverty reduction and may crowd out poverty-focused spending. Studies to evaluate the economic and financial viability of the projects and assess their fiscal impact will be needed as a first step, and competitive international biddings will have to be conducted for their implementation.

50. Financial relations with public enterprises need to be clarified. In particular, the status of the liabilities of the enterprises to be privatized and their possible fiscal impact need to be established-including for SONAPRA and the telecommunications company, as well

${ }^{20}$ At end-2002, more than 80 percent of civil servants were 40 or older. The retirement age is 55 . 
as a plan to settle cross debts between the public utility companies and the government and prevent their recurrence.

51. The government deficit, including grants, will need to be kept in line with debt sustainability. To that effect, the debt committee, which was established in 2003, should play a key role in monitoring the borrowing requirement of the government, and reviewing the proposals for external financing, which should exclusively consist of grants and highly concessional loans.

52. Technical assistance in the fiscal area will still be needed to help the authorities attain these objectives, considering Benin's limited administrative capacity. The Fund could contribute in the form of follow-up missions (both from headquarters and the West Africa Regional Technical Assistance Center (West AFRITAC), further to the recent assessments of the revenue and customs administration, and of the public expenditure management reforms and monitoring capacity of poverty-reducing expenditures; meanwhile, the World Bank, for its part, is committed to continuing its assistance to the public expenditure and civil service reforms in the context of the PRSC.

\section{Structural reforms}

53. Following the mixed performance in recent years, a new impetus in the implementation of the uncompleted reform agenda is needed in order to improve the overall efficiency of the economy and delivery of service to the population, and make the economy more competitive.

54. The pace of implementation of the privatization program and establishment of the appropriate regulatory frameworks has been slow and needs to be accelerated in order to reach the PRSP objectives, including the privatization of the cotton parastatal, SONAPRA, of the electricity utility, SBEE, and of the telecommunications company, OPT, as well as the involvement of the private sector in the management of the Port of Cotonou. In parallel, there is a need to strengthen divestiture procedures and institution in order to ensure that privatization is implemented through a timely and transparent process.

55. Regarding the cotton sector, the next steps of the reform-to implement a successful transition to a system encouraging competition among ginners while eliminating the administrative allocation of seed cotton - still need to be defined. Formulation of the reform should benefit from the results of the study on the impact of past cotton sector reforms on poverty, which the World Bank has undertaken in collaboration with sector stakeholders. In the meantime, the privatization of SONAPRA will need to be completed in a transparent manner, the new private institutions managing the sector-including farmers' organizations - strengthened, and the producer price-setting mechanism made more responsive to changes in the world cotton price.

56. To promote private-sector-led growth, there is also a need to encourage private sector investment. To this end, the national strategy to fight corruption and the 
comprehensive program to reform and strengthen the legal and judiciary system need to be implemented forcefully. Furthermore, a thorough diagnostic of impediments to private sector development is scheduled to be carried out, on the basis of which a realistic private sector development strategy ought to be developed and implemented in partnership with the private sector.

57. The forceful implementation of the structural reform agenda will be key to strengthening Benin's competitiveness, as it will help contain public sector wage pressure, improve the delivery of public utilities and their costs, and enhance the efficiency of the Port of Cotonou

58. The World Bank will continue to play a lead role in supporting structural reforms in all these areas, through its PRSC as well as specific sector projects.

\section{Millennium Development Goals}

59. While most social indicators have improved since the 1990s, Benin's progress toward achieving the MDGs has been generally slow. Trends since 1990 suggest that (i) Benin would be on track to meet the goals on poverty, malnutrition, HIV/AIDS, and access to safe water; (ii) prospects for meeting the education goals are mixed; ${ }^{21}$ and (iii) the targets for maternal and infant mortality, and for access to improved sanitation would not be reached. ${ }^{22}$ Consequently, reaching the MDG targets, particularly in the area of women's education, sanitation, and children's and maternal health, would require designing sectoral programs that take account of the complementarity and the potential synergy among them. The World Bank and other donors have indicated their commitment to provide assistance in these areas. In parallel, the authorities should strengthen the institutional structure to implement and monitor the social policies in the PRSP effectively.

60. Elimination of subsidies in the cotton sector in the world's major cottonproducing countries would significantly help Benin reach the MDG target on poverty. Estimated at US\$5.4 billion for the 1998/99 crop season, these subsidies have been a major source of the downward pressure on world prices. ${ }^{23}$ Elimination of subsidies in the developed

${ }^{21}$ Although the primary education enrollment rate was already 70 percent in 2001 , its completion rate was still low (about 46 percent) and is unlikely to approach 100 percent by 2015. Moreover, gender inequality remains high.

${ }^{22}$ Based on past trends, Benin could reach a maternal mortality rate of 375 per 100,000 by 2015 , more than twice the MDG target rate (137 per 100,000). Benin has significantly reduced child mortality (from 170 per 1,000 live births in 1996 to 146 in 2002) but would still be far from the MDG target (60 per 1,000 births) by 2015 .

${ }^{23}$ Ousmane, Badiane, and others, 2002, "Cotton Sector Strategies in West and Central Africa,” IMF Working Paper 02/173 (Washington: International Monetary Fund). 
countries alone would raise world cotton prices by US $\$ 0.12$ per pound. In Benin, where the cotton sector is the major contributor to the livelihood of some 20 percent of the population, such an increase in world cotton prices would improve the revenues of the farmers by 20 percent annually.

\section{Design of future programs}

61. Drawing on the evaluation of past experience, shortcomings in the design and implementation of Fund programs should be addressed. The authorities have started tackling ownership issues by completing their PRSP, which is the result of broad-based consultations and contains a credible poverty reduction strategy, to be used as the only reference framework for national policies and the participation of development partners. However, the authorities would need to address the PRSP shortcomings identified in the Joint Staff Assessment (JSA) - to sharpen the poverty focus and make the strategy fully operationaland strengthen the institutional framework for the implementation of the PRSP. Fostering ownership will also require improved transparency in the privatization process - with the support of the World Bank, as was the case with the privatization of SONAPRA -24 and consensus building, particularly regarding the privatization of the port and the preparation of a new civil service reform strategy. To minimize risks to structural reform implementation, safeguards could be built into future programs, through the use of prior actions and in close coordination with the World Bank (as in the last PRGF review, regarding SONAPRA privatization). To improve policy response to external shocks, programs could also include alternative contingent scenarios.

\section{Future Fund RELATIONS With BENIN}

62. The authorities have indicated their interest in having a successor PRGF arrangement. They have noted that, in spite of the progress accomplished over the past decade, Benin's economic and financial situation remains fragile and highly vulnerable to external shocks, given its dependence on the cotton sector, trade with Nigeria, and international financial assistance. Also, the structural reform agenda remains to be completed, in order to develop an environment conducive to higher investment and private-sector-led growth. Furthermore, progress in reducing poverty is still elusive, and success in this area will require targeted and sustained efforts to implement the poverty-reducing strategy, as elaborated in the PRSP, and to reach the MDGs.

\section{The staff agrees that a follow-up PRGF arrangement with low access would help the authorities prepare and implement the policies aimed at accelerating growth and}

${ }^{24}$ An investment bank was recruited through a competitive bidding process in May 2003 to help the authorities carry out a fully transparent privatization. 
reducing poverty. ${ }^{25}$ Fund involvement should accordingly help preserve a stable macroeconomic framework and focus on the reforms pertaining to the core areas of the Fund, including domestic revenue mobilization, public resource management, external debt management, government contingent liabilities, and integrating the PRSP into a sound multiyear macroeconomic framework. Annual programs should be aligned with PRSP objectives. Continued Fund involvement would also facilitate the mobilization of concessional international financial support, and it would provide a framework for sound policy response in case of exogenous shocks - in accordance with the lessons drawn for the design of future programs in the previous section. Indeed, during the recent experience with an unexpected drop in the world cotton price in the second half of 2001 the PRGF framework was critical for permitting a onetime subsidy to producer price without compromising the fiscal and sectoral reform objectives, as it helped mobilize exceptional external financial budgetary support and complement it through spending cuts in nonpriority sectors.

64. In collaboration with the World Bank and other donors, a Fund-supported program would also encourage an acceleration of the structural reforms - including the divestiture agenda, civil service reform, and the liberalization of the cotton sector-and the implementation of the poverty reduction strategy. As indicated above, safeguards could be built into the programs to minimize risks to structural reform implementation.

65. The risks facing Benin in achieving its PRSP objectives, including in particular the economy's vulnerability to external shocks, weak institutional capacity, and reform slippages, will have a bearing on future Fund engagement. To mitigate these risks, a strong program ownership will be necessary, together with significant up-front actions in the areas mentioned above.

66. A successor arrangement should have as a key objective Benin's graduation from the use of Fund resources upon its completion; this will require strong progress in the implementation of the remaining key reforms, as well as in the buildup of the capacity of the authorities to design and monitor its program, mobilize and coordinate foreign assistance, and implement poverty-reducing expenditure. Such progress, and attendant improvement in financial and economic conditions, will need to be assessed regularly during the program. Following graduation from the use of Fund resources, the Fund may be expected to continue to provide technical assistance, particularly in budget formulation and expenditure management, and to help the authorities monitor economic and financial developments closely, to sustain the mobilization and effective utilization of concessional financial assistance.

${ }^{25}$ Annual balance of payments gaps are estimated at about 2 percent of GDP in the coming years, reflecting the additional spending needed to meet the PRSP objectives. These needs are expected to be covered by external budgetary assistance in the form of grants and by highly concessional loans from bilateral donors and multilateral institutions. 


\section{Box 1. Benin: Sources of Growth}

A growth-accounting framework based on a Cobb-Douglas aggregate production function with constant returns to scale was used for the analysis:

$$
Y=A K^{\alpha} L^{1-\alpha}
$$

where $Y$ is real GDP, $A$ is total factor productivity (TFP), $K$ is physical capital, $L$ is the labor force, and $\alpha$ is the elasticity of output with respect to capital. The series for the stock of capital was constructed using the perpetual inventory method and assuming a constant depreciation rate of 5 percent and a capital-output ratio of 1.5 in the initial year (1970). Active population (age 15 and up) was used as a proxy for total labor force. The elasticity of output with respect to capital was assumed to be equal to 0.35 , in line with estimates obtained for many other developing countries (ranging from 0.3 to 0.4 ).

The decomposition of the sources of growth was effected over three distinct subperiods: (i) 1980-88, a period of a socialist regime and a centrally planned economy; (ii) 1989-93, a period of economic liberalization accompanied by far-reaching structural reforms; and (iii) 1994-2003, which was characterized by improved competitiveness of the economy, fiscal consolidation, and a deepening of structural reforms.

The results obtained (see table below) show that the low economic growth experienced in the 1980s was accompanied with a negative contribution of total factor productivity. In contrast, the substantial increase in real GDP growth during 1994-2003 was the result of (i) a larger contribution from capital accumulation, reflecting increased private and public investment; and (ii) a positive contribution of total factor productivity, generated by gains in increased efficiency of the factors of production. The turnaround in TFP performance in the recent period reflects in large part progress achieved in implementing structural reforms.

Benin: Decomposition of Economic Growth, 1980-2003

\begin{tabular}{lccc}
\hline & $1980-88$ & $1989-93$ & $1994-2003$ \\
\hline Real GDP growth (in percent) & 2.1 & 2.5 & 5.1 \\
Contribution from (in percentage points): & & & \\
$\quad$ Physical capital & 1.1 & 0.7 & 1.6 \\
Labor force & 1.7 & 2.0 & 2.2 \\
$\quad$ Total factor productivity & -0.7 & -0.2 & 1.2 \\
\hline
\end{tabular}

1/ This value for the elasticity of output to capital has been widely used in other studies on developing countries (see for example B. Bosworth and B.M. Collins. "The Empirics of Growth: An Update," Brookings Panel on Economic Activity, September 2003). 


\section{Box 2. Benin: Civil Service Reform}

Civil service reform has been a key component of government program since 1989. The initial objectives of the reform were to contain the wage bill and strengthen the efficiency of public administration. Measures included (i) a voluntary departure scheme, which was implemented during 1990-96 and led to more than 6000 departures; (ii) a wage freeze which lasted from 1987 to $1992{ }^{1}$ and (iii) an attrition policy that allowed only two replacements for every three departures. These measures led to a reduction of permanent civil servants from about 37,400 (excluding military personnel) in 1990 to about 30,000 in 2000, and a fall of the wage bill from 7.2 percent of GDP to 4.6 percent over the same period.

Since 1996, the reform efforts have concentrated on replacing the automatic advancement system by a performance-based compensation system. Preparation of a new pay scale and a performancebased compensation mechanism, with World Bank assistance, was completed in early 1998. However, the envisaged reform stalled, as the National Assembly did not vote on the amendments to the law required by the Constitutional Court and trade unions were strongly opposed to it. To overcome the blockage of the reform, the government started to apply in early 2003 a recruitment policy based on fixed-term contracts to replace retiring civil servants. To this end, a law establishing a legal framework for fixed-term contract government employees was approved by the government and submitted to the Supreme Court for legal advice. Moreover, discussions were initiated with trade unions on a new civil service reform strategy that would include (i) the progressive extension of initial fixed-term contracts for all new recruitments; (ii) the adoption of a single statute for government employees covering both civil servants and contractual employees; and (iii) a revised performance-based promotion and remuneration system. Preparation of this new strategy has already been started.

The increasing number of civil servants reaching retirement age, together with the decline in the number of contributing civil servants, has substantially affected the financial viability of the civil service pension fund (FNRB). ${ }^{2}$ In this respect, the authorities have finalized the terms of reference for an actuarial study and started the process of hiring a consultant to this end. A strategy to eliminate the medium-term financial deficit of the FNRB will be elaborated this year, on the basis of the recommendations of the actuarial study.

1/ The authorities froze wages, but not the automatic advancements every two years. The discrepancy between actual salary payments and grade-based salaries has been gradually closed since 1992 and civil service wages are now in line with the grade scale reached in 2004. However, the financial benefits resulting from promotions received by civil servants during 1987-92 were not granted. Civil service trade unions have requested retroactive pay of these benefits. A commission comprising government and trade unions representatives is examining the demands.

2/ At end-December 2002, about 82 percent of civil servants were 40 and more years old and the FNRB's deficit reached 48 percent of its total expenditure. The FNRB's deficits have been automatically covered by budgetary transfers (about 0.4 percent of GDP in 2003). 


\section{Box 3. Benin: Poverty Reduction Strategy Paper (PRSP)}

The Executive Boards of the Fund and the Bank discussed the PRSP and endorsed the Joint Staff Assessment (JSA) in March 2003.

PRSP objectives. The poverty reduction strategy of the PRSP is centered around four pillars:

- Strengthening of macroeconomic stability through sound fiscal and monetary policies and a stronger growth performance led by the private sector.

- Improvement of human capital and environmental management through measures and performance targets in education, health, drinking water, housing, rural electrification and roads, nutrition and food security.

- Strengthening of governance and institutional capacity through the implementation of the anticorruption plan adopted in 2002; acceleration of administrative reform and decentralization; strengthening of the judicial system and democratic structure; and, continued implementation of the public expenditure reforms.

- $\quad$ Promotion of sustainable employment opportunities and strengthening of the capacity of the poor to participate in the decision making through development of small business and microfinance; community development; and improvement of social security.

The JSA considered the PRSP as providing an adequate framework for reducing poverty but identified a number of areas where it should be improved, including the poverty diagnosis, the strategy for private-sector-led growth, and the mechanisms for monitoring and evaluation of PRSP outcomes. The authorities started in early 2003 to address these shortcomings. To improve the poverty diagnosis, a national household survey on living conditions has been conducted, and a poverty and social impact analysis (PSIA) of cotton sector reforms has been undertaken, with the assistance of the World Bank. In addition, the mechanism for monitoring and evaluating the PRSP implementation is being strengthened, with the assistance of bilateral donors. However, the strategy for private-sector-led growth remains to be elaborated.

Indicators in the PRSP cover most of the Millennium Development Goals (MDGs). The targeted reduction in poverty is consistent with the MDG target of halving poverty by 2015 . The target for primary school enrollment, which is set at 100 percent by 2015, is less ambitious than the MDG of universal primary completion. The infant mortality rate is targeted to be reduced by two-thirds in line with the MDG target and past performance. The PRSP does not present targets either for maternal mortality or for access to reproductive health services, but conservative medium-term targets are set for assisted birth, prenatal consultations, and contraceptive prevalence. The goal of universal access to safe water is targeted to be reached in 2010, in advance of the MDG time frame.

Progress report of the implementation of the PRSP. In January 2004, the authorities completed the first progress report on the implementation of the PRSP during the first half of 2003, which highlighted the need to intensify efforts to improve the PRSP and its implementation, including through higher execution rates in social expenditures and acceleration of structural reforms. The first annual assessment of the poverty reduction strategy, covering the entire year of 2003, is scheduled to be finalized in the first half of 2004. 
Figure 1. Benin: Output, Prices, and Real Exchange Rates, 1989-2003 (Annual changes in percent, unless otherwise indicated)
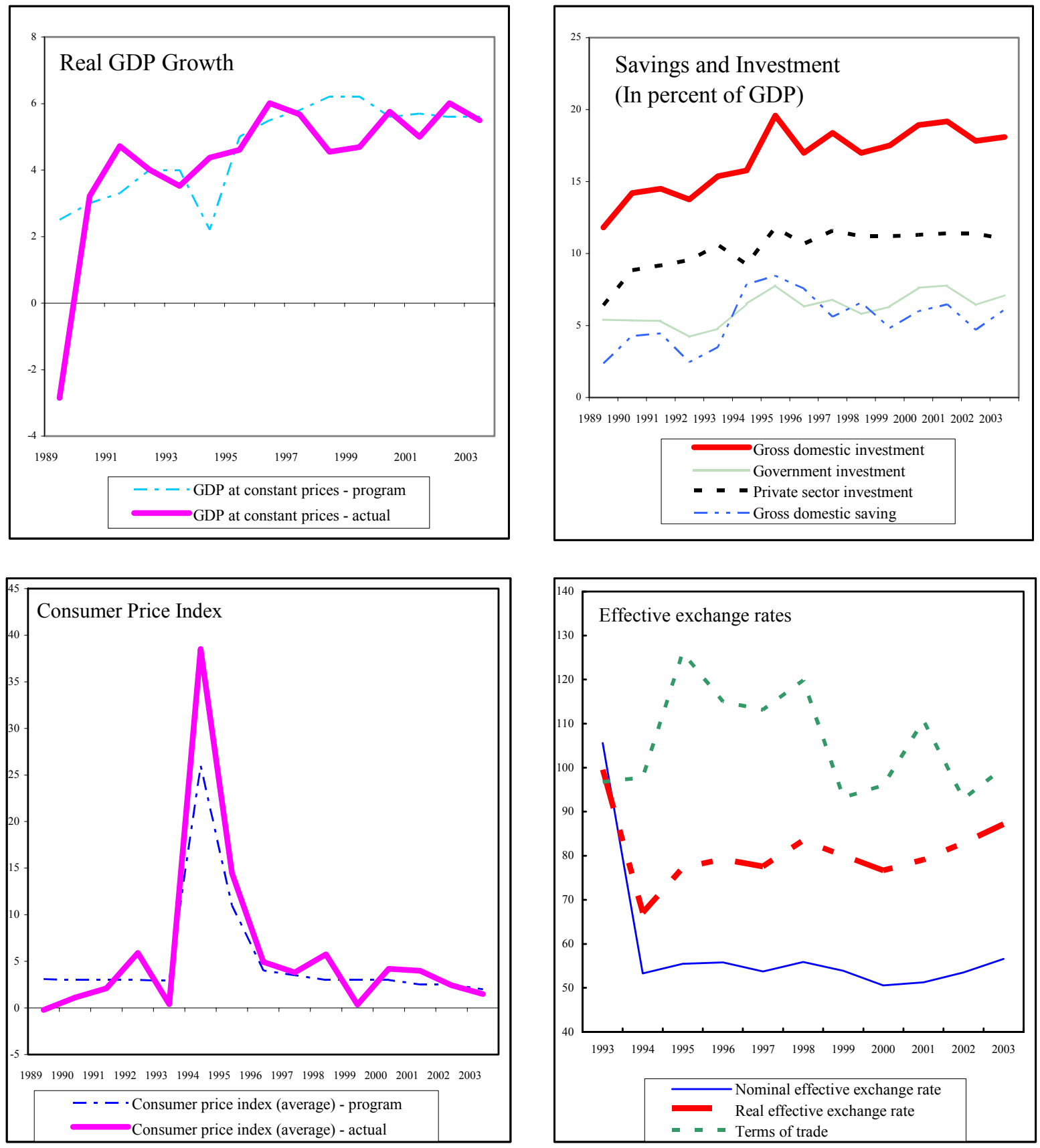

Sources: Beninese authorities; and staff estimates. 
Figure 2. Benin: Government Finance and Monetary Indicators, 1989-2003 (In percent of GDP, unless otherwise indicated)
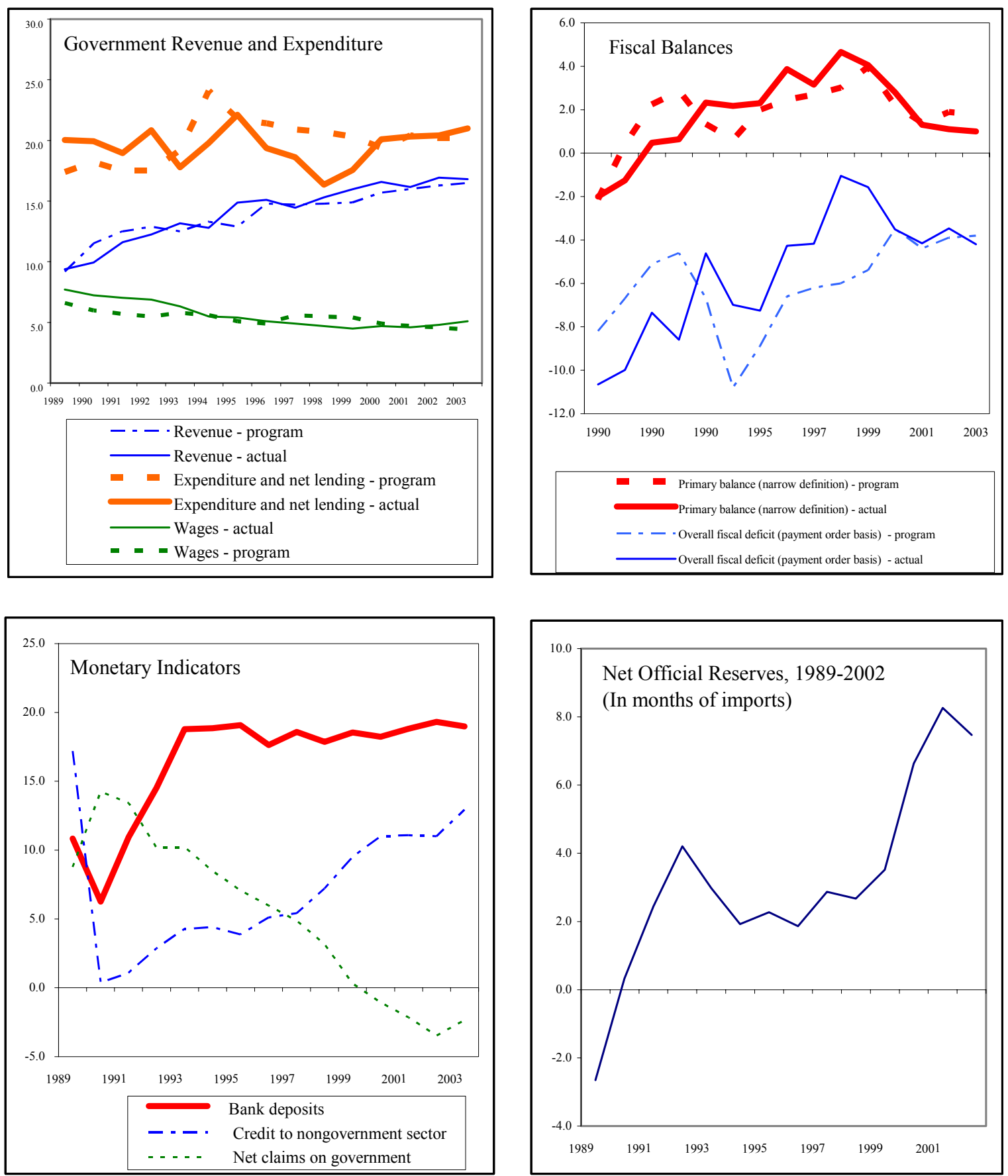

Sources: Beninese authorities; and staff estimates. 


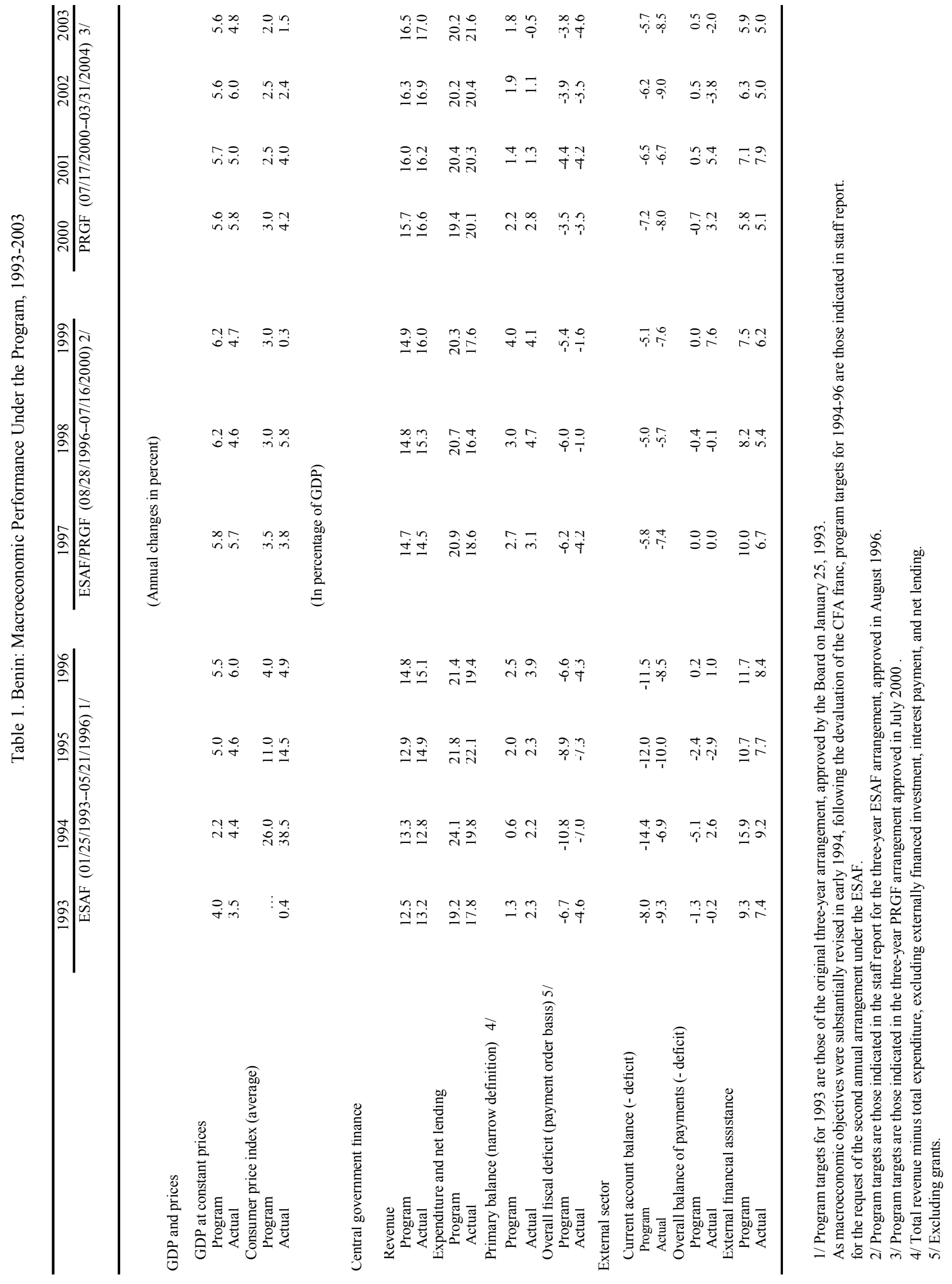




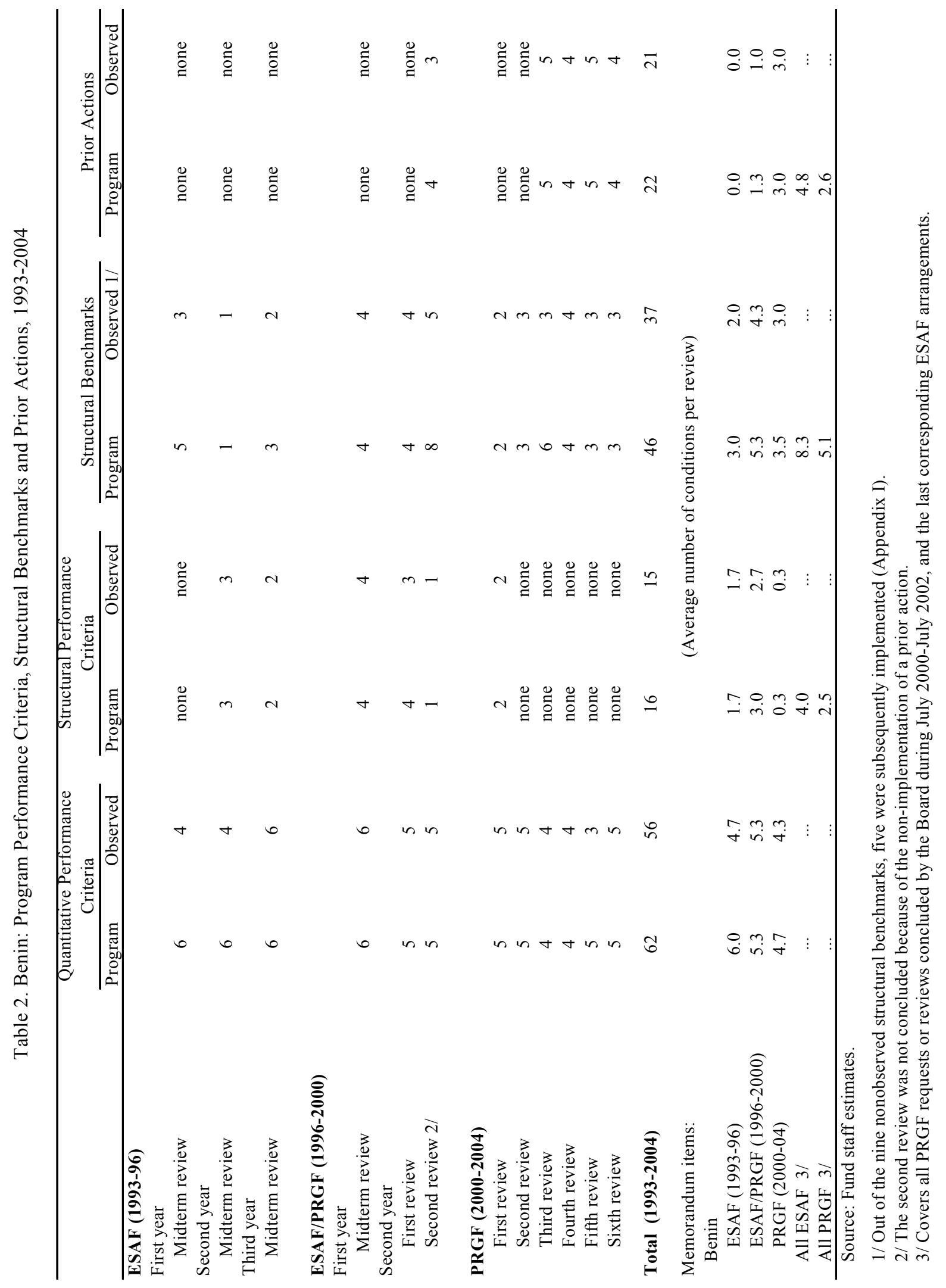




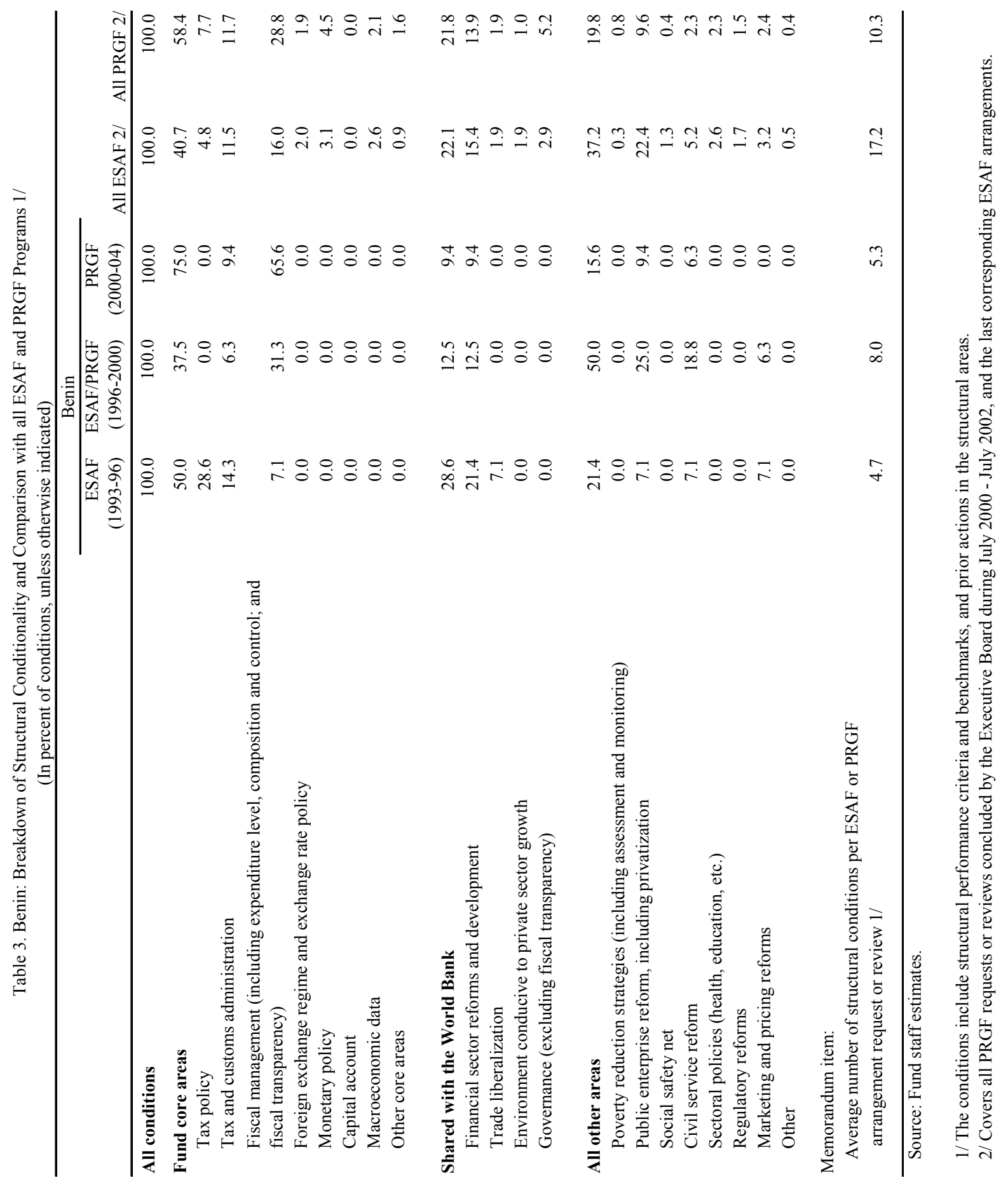




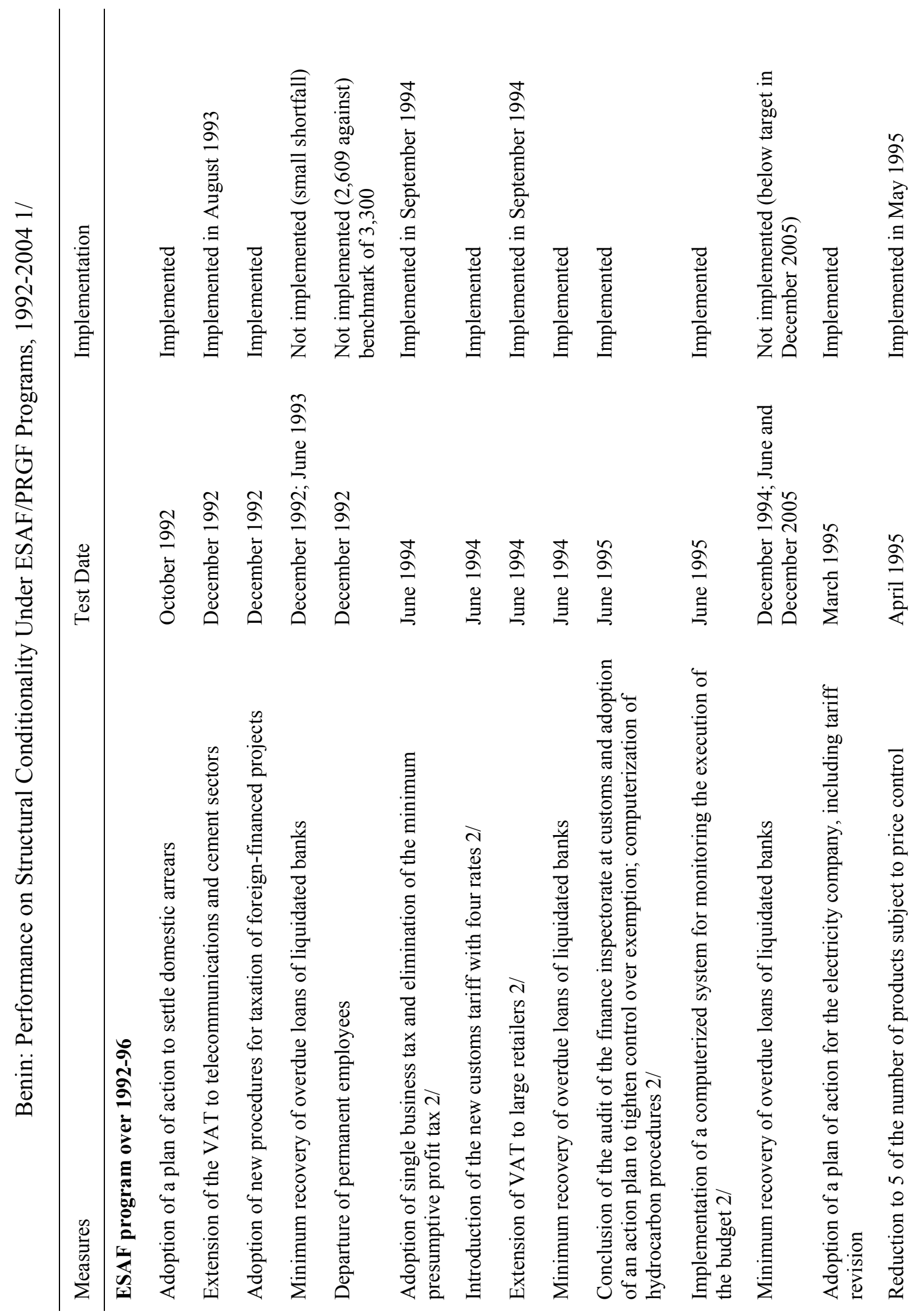




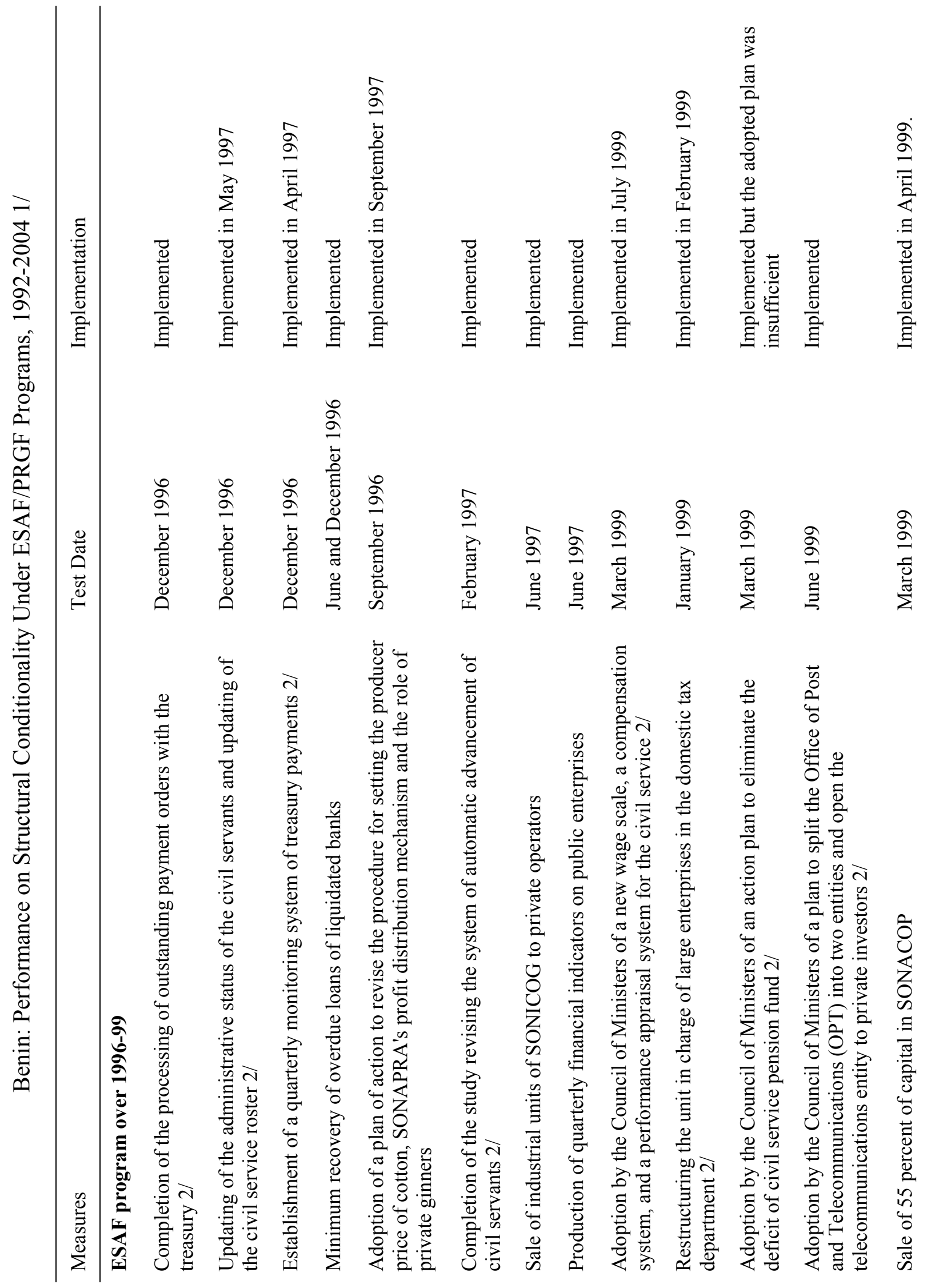




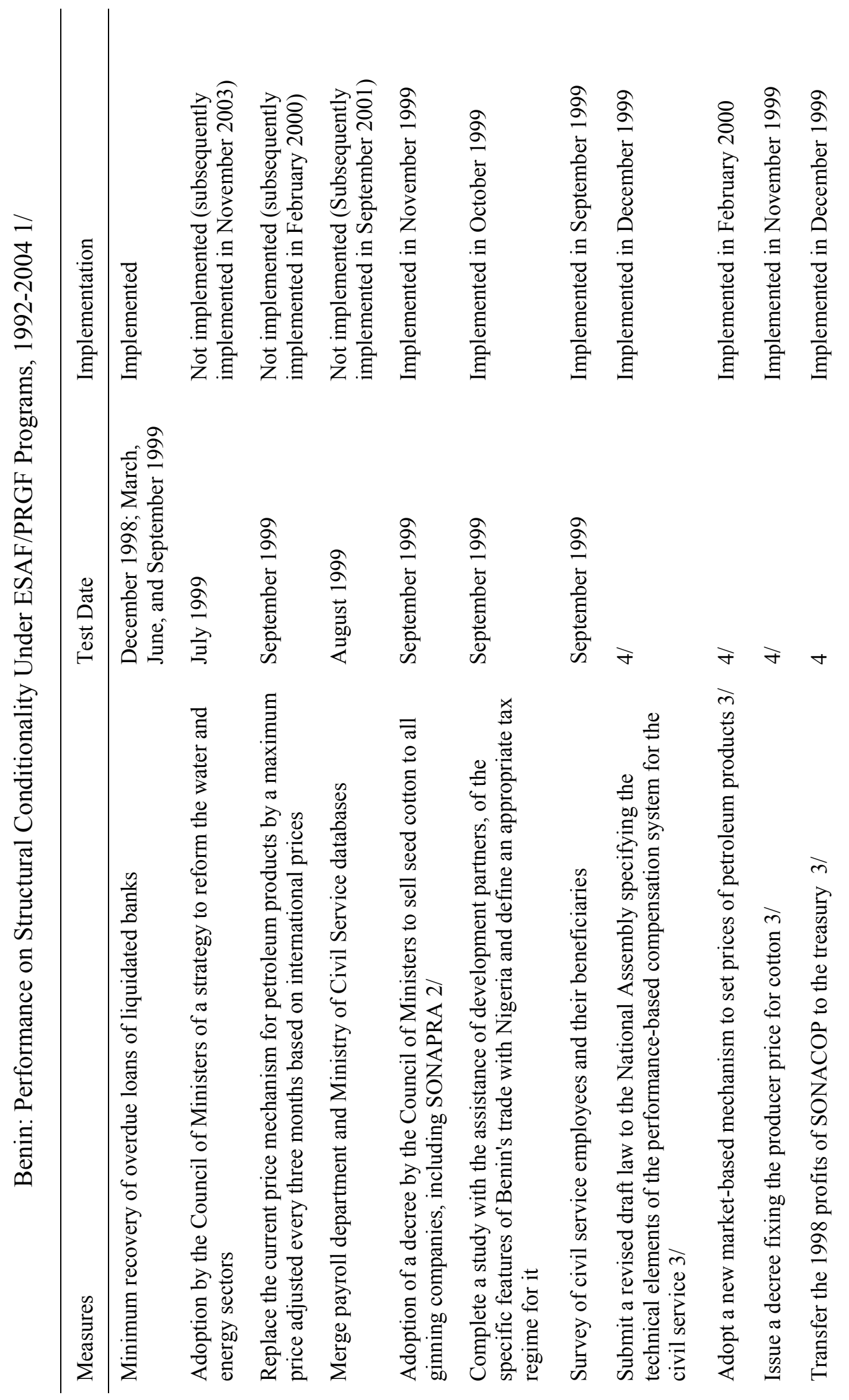




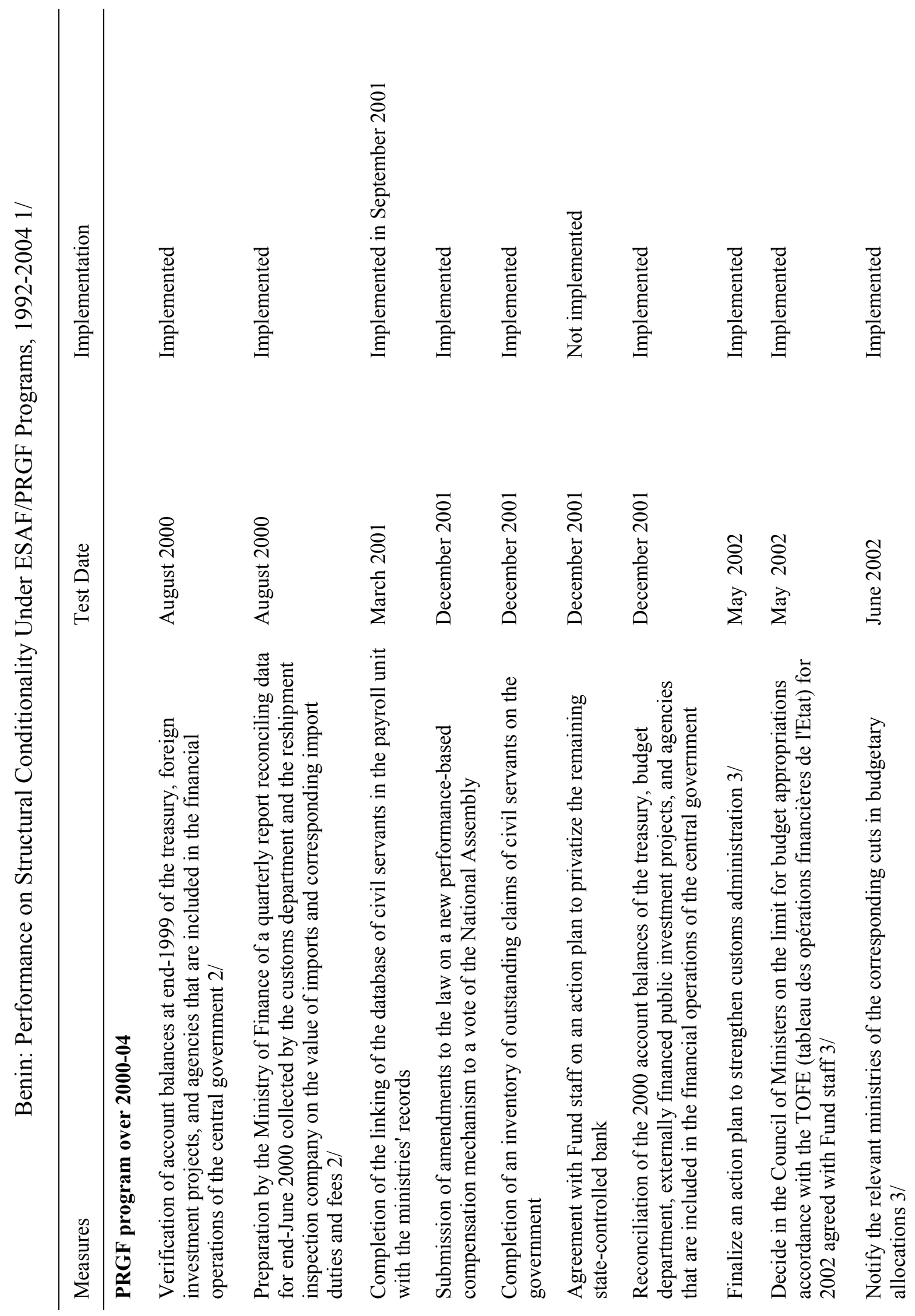




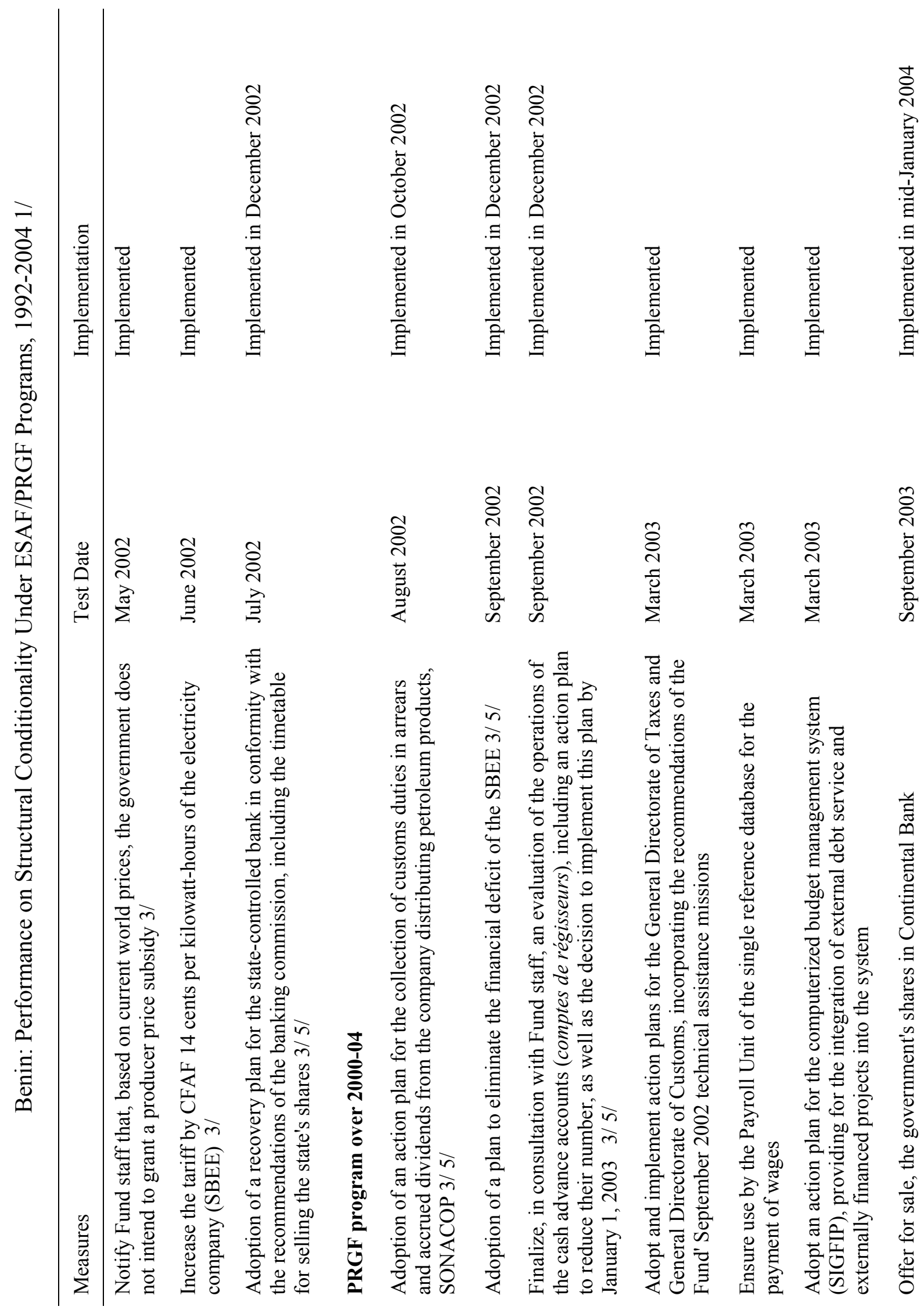




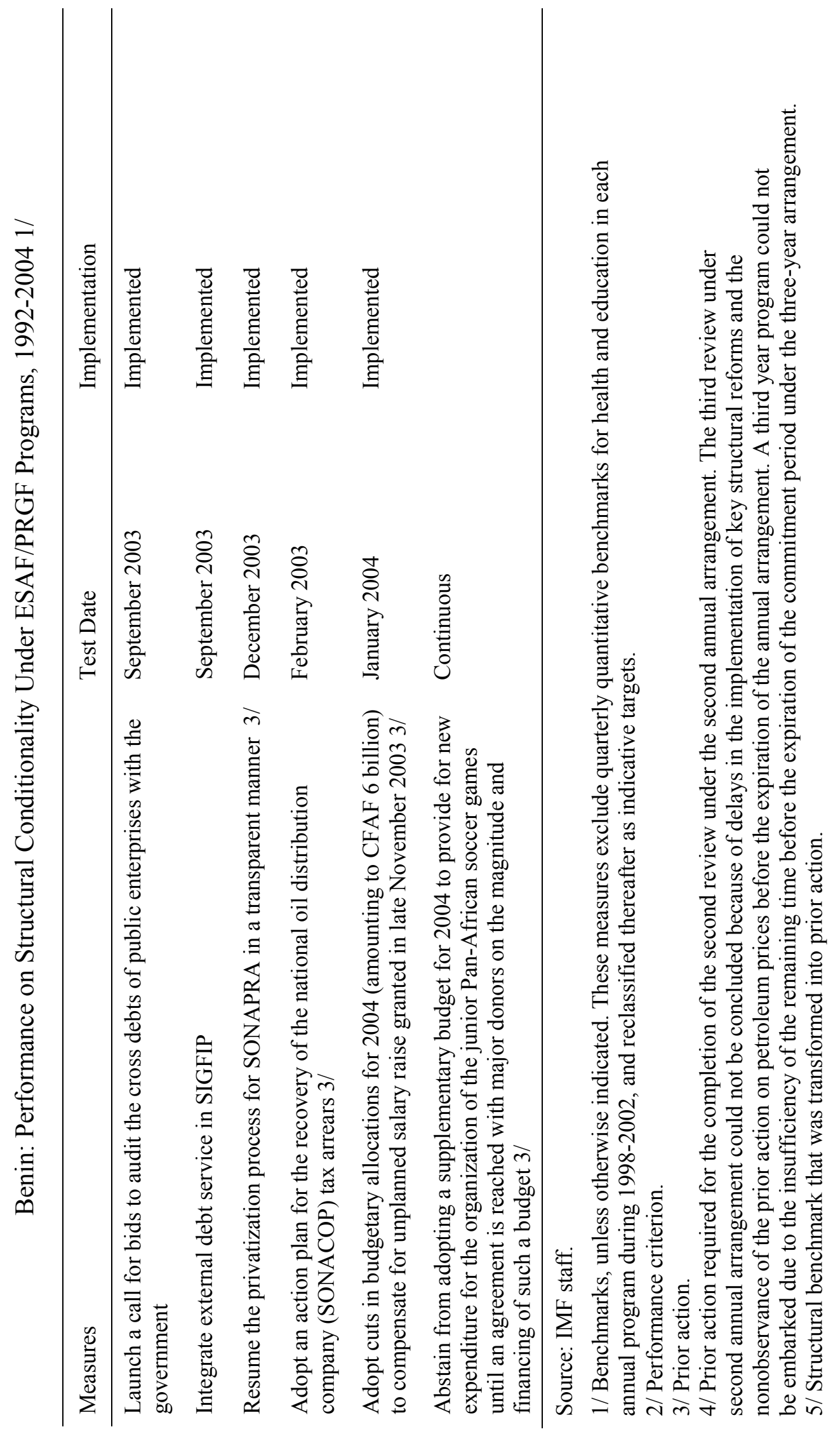

